\title{
Relationships Between Green Supply Chain Drivers, Triple Bottom Line Sustainability and Operational Performance: An Empirical Investigation in The UK Manufacturing Supply Chain
}

\author{
Susmita Pattnaik \\ Manager, HR \& Operations, Codaemon Softwares Pvt. Ltd., \\ Hadapsar, Pune, Maharashtra, India. \\ Email: sushmita.pattnaik@gmail.com \\ Subhra Pattnaik \\ Lecturer, Xavier School of Human Resource Management \\ Xavier University, Bhubaneswar, Harirajpur, Odisha, India. \\ Email: subhrafrends@gmail.com (Corresponding Author)
}

\begin{abstract}
Sustainability has assumed salience over the past years, thereby becoming a corporate mantra as well as a promising research area. Most sustainability studies have focused on environment friendly operations contributing to the concept. However, sustainability extends beyond environmental performance to also encompass economic and social performance. All the three factors combine to form the 'Triple bottom line (TBL) performance'. This paper is an empirical investigation of the effect of green supply chain (GSC) drivers on the TBL performance and the influence of TBL performance on operational performance of manufacturing companies in United Kingdom (UK). Structural equation modelling (SEM) was used to reveal that GSC drivers like supplier and customer pressure and environmental purchasing positively influenced social and economic performance respectively, whereas ecodesign and production influenced all the three parameters of TBL performance. It was interesting to find that social and economic performance, but not environmental performance, had a significant positive influence on firm's operational performance.
\end{abstract}

Keywords: green supply chain, sustainability, triple bottom line performance, operational performance

\section{INTRODUCTION}

The realization of human race that it is unethical to put the future generation at stake for business profits led to the evolution of the concept called 'sustainability' (Gunasekaran and Spalanzani, 2011). Today, a firm's sustainable practices influence its public image as well as act as stakeholder evaluation parameter of the firm (Bals and Tate, 2017; Ozanne et al., 2016). In a survey conducted across 2500 companies, $65 \%$ companies listed sustainability on their top ten agenda (Kiron et al., 2015). Since early 1990's corporates have placed huge emphasis on environmental sustainability to the extent of the term being described as 'the corporate mantra' by Sarkis (2001). It is a common understanding that environmental strategies lead to successful and robust sustainability models (Wilson, 2015). Environmental sustainability is firmly linked with corporate social responsibility (McLean, 2019) and corporate governance policies (Hussain et al., 2018) of giant firms like Google or Walmart. However, at times, these progressive companies too have been criticized for people issues or working conditions, which leads us to believe that sustainability also strongly encompasses the social dimension and is not only about the environmental dimension (Gimenez et al., 2018). At the same time, economic dimension cannot take a backseat because firms exist to make profits. In fact, at times firms seek immediate economic gains from their environmental and social strategies, thereby overemphasizing economic performance and neglecting the balance between the three dimensions (Gao and Bansal, 2013). The concept of TBL proposes maintaining a balance between environmental, social and economic performance for businesses to be competitive and truly sustainable (Carter and Rogers, 2008; Gimenez et al., 2018). However, integrating all the three dimensions into the business sustainability framework is a complex process and not many companies have been able to manage it successfully (Kiron et al., 2015). In fact, TBL implementation poses a serious challenge to firms trying to be sustainable in the true sense (Ahi and Searcy, 2015; Klumpp, 2018). Further, there is a dearth of research on TBL as the focus primarily has been only on environmental sustainability till date (Bastas and Liyanage, 2018; Rajeev et al., 2017; Svensson et al., 2016). Many studies have focused on drivers positively influencing environmental performance of the supply chain, or GSC. However, not enough number of studies have focused on integrating the drivers of social and economic dimensions in environmental sustainability frameworks (Delmas and Montiel, 2009; Rajeev et al., 2017).Ozanne et al. (2016) stated that there most studies on integrating TBL dimensions 
together are conceptual in nature, with less focus on empirical ones. Van der Byl and Slawinski (2015) stated that often, the TBL dimensions compete with each other, creating tensions in sustainability strategies. This is another reason for dearth of empirical studies in this area. However, the authors urged researchers to explore solutions to these tensions since "there is a benefit to acknowledging the coexistence of contradictory elements or tensions" (p. 59). There is a scarcity of established research theories and frameworks when it comes to TBL sustainability (Ahi and Searcy, 2015). Alhaddi (2015) also reported the mixing up of the two terms - TBL and sustainability in sustainability literature where papers have used the term - 'TBL' but have not really looked into all the three dimensions of TBL sustainability. Rajeev et al. (2017) urged researchers to carry out industry specific research on TBL sustainability to close the gap that exists in this area and gain further insights into this comparatively scarcely explored area in the field of sustainability.

This paper responds to call of researchers like Bastas and Liyanage (2018), Rajeev et al. (2017), Svensson et al. (2016), or Van der Byl and Slawinski (2015) to further the research work on TBL sustainability and provides an empirical investigation into the relationship of the drivers of the GSC with the environmental, social and economic performance of the firm. It also studies the relationship between the TBL performance and the operational performance of the firm, thereby contributing to a gap in the sustainability literature and surfacing significant implications for businesses.

As advised by Rajeev et al. (2017), this paper focuses specifically on manufacturing sector of UK to be able to better understand and apply the empirical findings in a particular context and suggest specific interventions that could benefit the firms in that sector. It is also unique as no such study has been done in the UK manufacturing sector to the best of the authors' knowledge. Recent studies on manufacturing set up (e.g., Ahmad et al., 2019; Junior et al., 2018; Shankar et al., 2017) have been mostly review or conceptual papers and not empirical studies focusing on the relationships between GSC drivers, TBL dimensions, and operational firm performance. Hence, this paper contributes uniquely to the TBL sustainability literature by empirically investigating these relationships in the UK manufacturing sector.

\section{LITERATURE REVIEW AND HYPOTHESIS DEVELOPMENT}

Sustainable practices have become increasingly important for firms to survive and succeed (Kiron et al., 2015). Initially, the focus of firms was limited to only achieving operational sustainability (Carter and Rogers, 2008; Faisal, 2010). However, today, the scope of sustainability has increased beyond a firm's boundary (Famiyeh et al., 2018) to also include sustainable supply chain (Ciccullo et al., 2018; Liu et al., 2018; Linton et al., 2007). While trying to integrate sustainable practices with supply chain, most firms have focused on environmental sustainability (McLean, 2019) as they believe that there is a strong linkage between successful environmental strategies and economic performance of firms (Wilson, 2015). Extant literature on sustainability on supply chain takes this environmental view to coin the term GSC (Delmas and Montiel, 2009; Rao and Holt, 2005; Vachon and Klassen, 2006) that has been defined in many ways. The definitions include the concept of green purchasing, or integrated supply chain flowing from supplier to manufacturer and then to customer and then reverse logistic (Zhu et al., 2017). Clearly, the emphasis is on the environmental dimension. A firm could be environmentally sustainable by adopting GSC management practices like green inbound logistics, internal supply chain (production), outbound logistics and reverse logistics (Rao and Holt, 2005), green supplier selection and improving supplier green practices (Rao, 2002, Zhu et al., 2017). Environmental performance of the firm is its ethical responsibility, which is also related to its social responsibility (Carter and Jennings, 2004; Quarshie et al., 2016) and goes beyond mere regulatory compliance (Melnyk et al., 2003). Thus, Judge and Douglas (1998, p. 245) defined environmental performance as: “... firm's effectiveness in meeting and exceeding society's expectations with respect to concerns for the natural environment. This desired end would extend beyond mere compliance with existing regulations to a proactive stance concerning future environmental considerations",

However, to be truly sustainable, firms also need to look at other dimensions of sustainability such as social and economic performance (Gimenez et al., 2018) and explore the concept to its fullest (Paulraj, 2011). Lindgreen et al. (2008, p. 447) stated that social performance relates to "... how [well] companies contribute to the well-being and quality of life of society and individuals in current and future generations." Consumers' awareness and Government regulations have forced companies to focus on social performance by being more sensitive to issues like human rights and safety (Carter and Jennings, 2004).Economic performance is about higher productivity, improved efficiency, reduction of operating cost, better utilization of natural resources, improved revenue and increase in market share (Rao and Holt, 2005) and avoiding legal fees. Zhu et al. (2007) defined economic performance as “... positive economic improvements, including decrease of cost for materials purchasing, decrease of cost for energy consumption, decrease of fees for waste treatment and waste discharge, and decrease of fines for environmental accidents" (p. 1045).TBL sustainability concept does this by encompassing all the three dimensions of sustainability, namely, environmental, social, and economic performance. Carter and Rogers (2008, p. 368) define TBL sustainable supply chain management as "... the strategic, transparent integration and achievement of an organization's social, environmental, and economic goals in the systemic coordination of key inter-organizational business processes for improving the long-term economic performance of the individual company and its supply chains. '

Unfortunately, most sustainability literature has focused on environmental performance with little focus on integrating social and economic performance into it (Hussain et al., 2018). While implementing TBL sustainability as emerged as a true challenge for firms (Ahi and Searcy, 2015; Klumpp, 2018), there is also scarce research on this particular area of sustainability (Ozanne et al., 2016; Shrivastava, 1995; Svensson et al., 2016). Social and 
economic dimension of TBL performance have not gained as much focus as the environmental dimension, though they hold as much importance for a firm's success and competitiveness (Bastas and Liyanage, 2018; Rajeev et al., 2017).

Further, Carter and Jennings (2002) or Quarshie et al. (2016) suggested that there is a link between environmental and social responsibility (human rights, safety, and philanthropy) in logistics. Carter and Rogers (2008, p.370) indicated that "...there are a variety of environmental and social issues that a firm can undertake which can both improve as well as harm the economic bottom line." Wu and Pagell (2011) and Zsidisin and Hendrick (1998) stated that environmental initiatives need huge investment and redefining existing systems that might be a trade off with the economic profits of the organization. Van der Byland Slawinski (2015) also stated that the three TBL dimensions are competing with each other and are interlinked. Improving environmental supply has been stated as beneficial as it can reduce costs and improve operational performance (Bowen et al., 2002; Carter et al., 2000; Walker et al., 2008). The above studies suggested that a firm's environmental, social and economic performances are interlinked and could also influence the operational performance. However, there has not been much research on the relationships between the three dimensions of sustainability with the operational performance of the company (Rajeev et al., 2017). Hence, it would be interesting to conduct an integrative study involving all the three dimensions of TBL performance, study the influence of GSC drivers on TBL sustainability as well as check the influence of TBL sustainability on the operational performance of firms. Such studies combining all three dimensions of TBL performance to develop a TBL sustainability model have not been explored much (Ahi and Searcy, 2015; Ozanne et al., 2016).

What could be the drivers of TBL performance then? Coming to literature on GSC drivers, external factors like the customers of a company can be the end users in a B to C model or another company in the B to B model. With growing environmental awareness consumers prefer environmentally responsible companies (Rao, 2002). Besides it "Customers and other stakeholders do not always draw a line between the company and its suppliers" (Rao, 2002, p.632). Hence, companies prefer to deal with suppliers who are both environmentally and socially responsible and also put pressure on their existing suppliers for the same. Carter (2005) says purchasing social responsibility involves dimensions like environmental purchasing, sourcing from minority-owned group and human rights, safety, and philanthropy issues related to supply chain management. Similarly, the supplier put pressure on the focal company to be socially and environmentally responsible, so that they earn a reputation of dealing with a sustainable company. Thus, supplier and customer pressure is defined as suppliers' and customers' "... concern about the safety, environmental impact, and origin of products" (Salam, 2008, p. 366). Hence, the hypotheses proposed are:

Hypothesis 1: Supplier and customer environmental pressure is positively related to environmental performance of the firm.
Hypothesis 2: Supplier and customer environmental pressure is positively related to social performance of the firm.

Further, internal activities like purchasing, product design and production are core to any manufacturing set up (Ahmad et al., 2019; Shankar et al., 2017; Zhu et al., 2010).Hence, Environmental purchasing as well as Ecodesign and production are pertinent to a manufacturing firm to build a sustainable supply chain(Hu and Hsu, 2010; Zhu and Sarkis, 2006).Environmental purchasing refers to integration of the environmental goals with the purchasing activities of the company and its choice of supplier network (Sarkis, 2003).Zsidisin, and Siferd (2001, p. 69) defined environmental purchasing as: "Environmental Purchasing (EP) for an individual firm is the set of purchasing policies held, actions taken, and relationships formed in response to concerns associated with the natural environment. These concerns relate to the acquisition of raw materials, including supplier selection, evaluation and development; suppliers' operations; in-bound distribution; packaging; recycling; reuse; resource reduction; and final disposal of the firm's products",

Warner and Ryall (2001) and Darnall et al. (2018) identified that greener purchasing can get business benefits like reduction of environmental damage, reduction of cost to health, efficiency savings, compliance with legislation and market opportunities. It also has a positive impact on the financial performance of the firm (Feng et al., 2018; Yook et al., 2018). Thus, hypotheses proposed are:

\section{Hypothesis 3: Environmental purchasing is positively} related to environmental performance of the firm.

Hypothesis 4: Environmental purchasing is positively related to economic performance of the firm.

Eltayeb et al. (2011, p.501) defined Eco design and Production as:"...environmental-conscious design [and production] of a product and its packaging that aims at minimizing negative environmental impacts of the product and its packaging throughout its entire life and promoting positive environmental practices such as recycling and reusing of the product and its packaging."

Increasing environmental pressures and requirements for improving organization's environmental image have caused companies to re-evaluate the way they do business (Hick, 2000). The WEEE (Waste Electrical and Electronic Equipment) and regulations like RoHS (Restrictions of the use of Hazardous Substances) has been forcing companies to take responsibilities of which have high negative effect on the environment and broaden their environmental practices beyond their firm, to their suppliers and customers (Zhu et al., 2010). Therefore, companies are redesigning their production method to decrease the short and long term environmental impact (Zhu and Liu, 2010).

Design or production of products that is not hazardous influences the environmental and economic performance of the company (Zhu et al., 2010). Eco-design bring cleaner production, reduction of wastes and energy consumption during the use phase, higher product reliability, as well as easier maintenance, repair and recycling (Hemel et al., 1997) which will have a positive impact on the environmental 
performance (Feng et al., 2018). Zhu et al. (2010) suggest that production of eco-friendly products gives company a marketing advantage which leads to increase in revenue and market share, reduction in operating costs and new market opportunities. Thus, the hypotheses proposed are:

Hypothesis 5: Eco design and Production is positively related to environmental performance of the firm.

Hypothesis 6: Eco design and Production is positively related to economic performance of the firm.

Vachon and Klassen (2006) indicated that the companies to meet the environmental sustainability challenge follow an approach called product stewardship that includes activities such as reverse logistics, product recovery, and remanufacturing. They added that these activities require greater coordination with immediate customers and/or end consumers along with greater interaction with suppliers. Therefore, for companies who become responsible to develop a greener supply chain, collaborate with their customers and suppliers and to harness a mutual collaborative advantage (Vachon, 2007, Zhu et al., 2010). Yan et al. (2016) found that green component procurement collaboration helps to improve the supply chain performance and also the three dimensions of Sustainable development. Paulraj (2011, p. 26) stated that supplier and customer collaboration "... includes indicators that measure the extent to which firms (1) cooperate with their suppliers [and customers] to develop environmental strategies and (2) provide suppliers [and customers] with materials, equipment, specifications, as well as services to support their environmental goals."

Paulraj (2011) identified that the collaboration can improve the environmental impact of the company's existing product and can reduce the waste on the supply side. Thus, the seventh hypothesis proposed in this study is:

Hypothesis 7: Environmental collaboration with suppliers and customers is positively related to environmental performance of the firm.

Operational performance is defined as the"... actual impacts of green supply chain initiatives on operational performance of a firm such as cost reductions, product quality improvements, improvements in delivery and flexibility." (Eltayeb et al., 2011, p. 501). Melnyk et al. (2003) stated that Environmental Management System (EMS) of a company can help improve its operational performance. Furthermore, improving environmental performance like reducing pollution can increase the profit margin of the organization. Company that performs well to environmental standards can avoid increased costs (fines), increased external intervention in day-to-day operations and in extreme situations, insurance of cease orders unlike those companies who do not comply to the standards of EMS (Melnyk et al., 2003). Gimenez et al. (2018) and Pullman et al. (2009) stated that socially responsible practices directly improve the product quality which reduces the total cost. There are many prior researches that prove that operational efficiency i.e. better product design, improvement in lead time and lesser operating cost improves the economic performance of the firm. It can be assumed that the other way around (i.e. increase in economic performance can increase operational performance) is also possible. This is because if the economic performance (bottom-line) of the company will improve, they can invest more in facilities that can increase the operational efficiency of company further. Thus, hypotheses proposed are:

Hypothesis 8: Environmental performance is positively related to the operational performance of the firm.

Hypothesis 9: Social performance is positively related to the operational performance of the firm.

Hypothesis 10: Economic performance is positively related to the operational performance of the firm.

\section{RESEARCH METHODOLOGY}

A quantitative research method was used in this study. Primary data was collected from the UK manufacturing companies using a survey questionnaire which was pilot tested by sending to $30 \mathrm{UK}$ manufacturing companies prior to its distribution.

\subsection{Survey Instrument}

The items used in the questionnaire are presented in Table 1. The scale designed to measure the items used a 7 point Likert scale with 1 indicating strongly disagree to 7 indicating strongly agree.

Table 1 Items in the questionnaire

\begin{tabular}{|c|c|}
\hline Items & Source \\
\hline 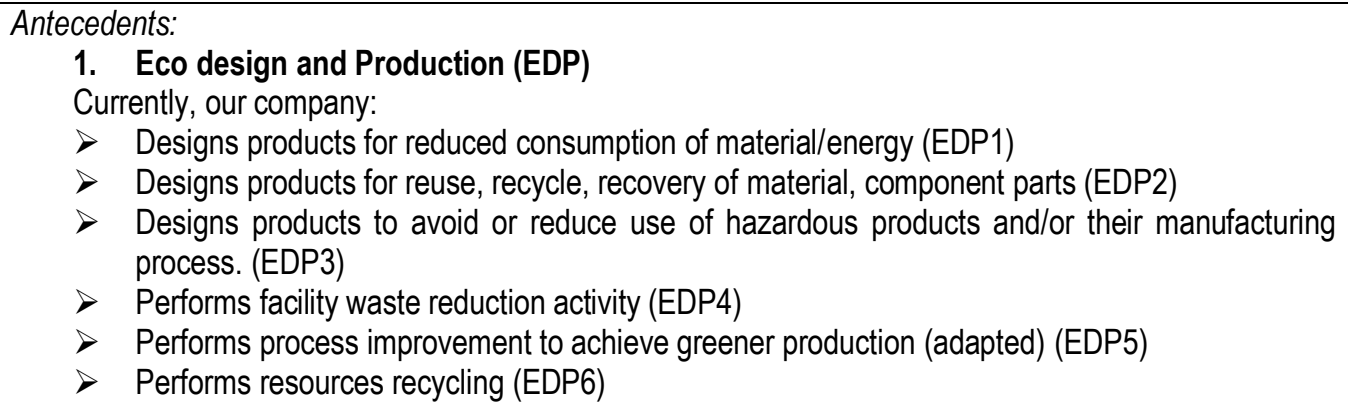 & $\begin{array}{l}\text { Adapted from (Zhu et al., } \\
\text { 2005) }\end{array}$ \\
\hline
\end{tabular}


Table 1 Items in the questionnaire (con't)

\begin{tabular}{|c|c|}
\hline Items & Source \\
\hline $\begin{array}{l}\text { 2. Supplier and Customer Collaboration (SCC) } \\
\text { Please indicate the extent to which you agree with the following: } \\
>\quad \text { We cooperate with our suppliers to achieve environmental objectives (SCC1) } \\
>\text { We work with our suppliers for cleaner production (SCC2) } \\
>\text { We collaborate with our suppliers to provide materials, equipment, parts and/or services that } \\
\text { support our environmental goals (SCC3) } \\
>\text { We cooperate with our customers to achieve environmental objectives (SCC4) } \\
>\text { We work with our customers for cleaner production (SCC5) } \\
>\text { We collaborate with our customers to provide materials, equipment, parts and/or services that } \\
\text { support our environmental goals (SCC6) }\end{array}$ & $\begin{array}{l}\text { Modified from (Paulraj, } \\
\text { 2011) } \\
\text { The items for supplier } \\
\text { collaboration were } \\
\text { repeated to measure } \\
\text { customer collaboration. }\end{array}$ \\
\hline $\begin{array}{l}\text { 4. Supplier and Customer Pressure (SCP) } \\
\text { My company's involvement in sustainability has been motivated by } \\
>\text { Social programs that our customers have in place (SCP1) } \\
>\text { Customers who seek socially responsible suppliers (SCP2) } \\
>\text { Increased awareness of social issues among our customers (SCP3) } \\
>\text { Social programs that our supplier have in place (SCP4) } \\
>\text { Supplier who seek socially responsible suppliers (SCP5) } \\
>\text { Increased awareness of social issues among our suppliers (SCP6) }\end{array}$ & $\begin{array}{l}\text { Adapted from (Carter } \\
\text { and Jennings, 2004) }\end{array}$ \\
\hline $\begin{array}{l}\text { 5. Environmental Purchasing (EP) } \\
\text { Currently, our company: } \\
>\text { Purchases recycled packaging (EP1) } \\
>\text { Purchases packaging that is of lighter weight (EP2) } \\
>\text { Uses a life-cycle analysis to evaluate the environmental friendliness of products and packaging } \\
\text { (EP3) } \\
>\text { Participates in the design of products for disassembly (EP4) } \\
>\text { Asks suppliers to commit to waste reduction goals (EP5) } \\
>\text { Participates in the design of products for recycling or reuse (EP6) }\end{array}$ & $\begin{array}{l}\text { Adapted from (Carter et } \\
\text { al., 2000) }\end{array}$ \\
\hline $\begin{array}{l}\text { Focal constructs (dimensions of sustainability) } \\
\text { 1. Environmental Performance (EnvPerf) } \\
\text { Please indicate the extent to which your company's involvement in sustainability has resulted in the } \\
\text { following outcomes: } \\
\\
\text { Reduction in air emission (EnvPerf1) } \\
\text { Reduction in waste (water and/or solid) (EnvPerf2) } \\
\text { Decrease in consumption of hazardous/harmful/toxic materials (EnvPerf3) } \\
>\text { Decrease in frequency for environmental accidents (EnvPerf4) } \\
\text { Increase in energy saved due to conservation and efficiency improvements (EnvPerf5) }\end{array}$ & $\begin{array}{l}\text { Adapted from (Paulraj, } \\
\text { 2011) }\end{array}$ \\
\hline $\begin{array}{l}\text { 2. Social Performance (SocPerf) } \\
\text { Please indicate the extent to which your company's involvement in sustainability has resulted in the } \\
\text { following outcomes: } \\
\\
\text { Improvement in overall stakeholder welfare or betterment (SocPerf1) } \\
\text { Improvement in community health and safety (SocPerf2) } \\
\text { Reduction in environmental impacts and risks to general public (SocPerf3) } \\
\text { Improvement in occupational health and safety of employees (SocPerf4) } \\
\text { (SocPerf5) }\end{array}$ & $\begin{array}{l}\text { Adapted from (Paulraj } \\
\text { 2011) }\end{array}$ \\
\hline $\begin{array}{l}\text { 3.Economic Performance (EcoPerf) } \\
\text { Please indicate the extent to which your company's involvement in sustainability has resulted in the } \\
\text { following outcomes: } \\
\\
\text { Decrease in cost of materials purchased (EcoPerf1) } \\
\text { Decrease in cost of energy consumption (EcoPerf2) } \\
\text { Decrease in cost for waste discharge (adapted) (EcoPerf3) } \\
\text { Improvement in return on investment (EcoPerf4) } \\
\text { Improvement in earnings per share (EcoPerf5) }\end{array}$ & $\begin{array}{l}\text { Adapted from (Paulraj } \\
\text { 2011) }\end{array}$ \\
\hline
\end{tabular}


Table 1 Items in the questionnaire (con't)

\begin{tabular}{|c|c|}
\hline $\begin{array}{l}\text { Consequence } \\
\text { 1.Operational performance (OperPerf) } \\
\text { Please indicate the extent to which your company's involvement in sustainability has resulted in the } \\
\text { following outcomes: } \\
>\text { Significantly reduced overall operational costs (OperPerf1) } \\
>\text { Significantly reduced lead times (OperPerf2) } \\
>\text { Significantly improved product quality (OperPerf3) } \\
\quad \text { products (OperPerf4) } \\
>\text { Significantly reduced waste within the production process (OperPerf5) }\end{array}$ & $\begin{array}{l}\text { Adapted from (Melynk et } \\
\text { al., 2003) }\end{array}$ \\
\hline
\end{tabular}

Note: The abbreviations in () has been used in the data analysis in section 5.

\subsection{Sample and data collection}

Senior managers (since they were believed to have accurate knowledge of the information asked in the questionnaire) of purchasing and operations departments of 1420 active UK manufacturing companies having more than 25 employees were contacted and the online survey link was emailed to them, followed by intermittent telephonic followups. The total number of responses obtained was 154 that make the response rate $9.22 \%$. However, out of 154 responses, 17 were unusable because of missing data. Therefore, the total number of usable responses was 130 .

\section{DATA ANALYSIS AND RESULTS}

The data analysis was done in two phases. In the first phase, measurement model analysis was done. The explanatory factor analysis (EFA) was done using SPSS 21 in order to extract the measures underlying each construct (Bayraktar et al., 2007). A series of confirmatory factor analyses (CFA)were performed to further check the reliability and validity of the items and to develop measurement models with acceptable fit to the sample data using AMOS 21. In the second phase, the hypothesized relationships were introduced in the model to obtain a structural model. The fitness of the structural model with the sample data was assessed and the path analysis was done to test the hypotheses.

\subsection{Measurement Model Analysis}

\subsubsection{Explanatory Factor Analysis}

EFA was done on 43 items using Direct Oblimin rotation and the extraction method used was Maximum Likelihood method. Four items that cross loaded (EDP5, SCC3, OperPerf4, and OperPerf5) were considered problematic and were removed one by one to obtain a better pattern matrix. The KMO value for the 39 items (after removal of the 4 problematic items) was 0.869 which indicated a distinct and reliable factor analysis as per Field (2005). The items loaded on to eight factors with Eigen value above one and explained $61.939 \%$ of the variance after rotation.

\subsubsection{Cronbach's Reliability Test}

The Cronbach's alpha coefficient for each construct was more than 0.8 (Table 2) that was more than the minimum value recommended by Hair et al. (2008) which is 0.7. Therefore, the scales were considered to be reliable.
Table 2 Cronbach's reliability test results

\begin{tabular}{|l|c|c|}
\hline Constructs & Cronbach's Alpha $(\boldsymbol{\alpha})$ & No of items \\
\hline SCP & .884 & 5 \\
\hline EP & .860 & 6 \\
\hline EDP & .829 & 5 \\
\hline SCC & .898 & 5 \\
\hline EnvPerf & .848 & 5 \\
\hline SocPerf & .866 & 5 \\
\hline EcoPerf & .891 & 5 \\
\hline OperPerf & .845 & 3 \\
\hline
\end{tabular}

4.1.3Confirmatory Factor Analysis - Measurement model, reliability and validity tests

CFA was carried out on the 39 items obtained after EFA. The measurement models for exogenous variables (SCP, EP, EDP, and SCC) and endogenous variables (EnvPerf, SocPerf, EcoPerf, OperPerf) were estimated differently as done by Corsten and Felde (2005) in their analysis. The convergent and discriminant validity test were done separately on both the models. The Average Variance Extracted (AVE) and Composite Reliability (CR) for the convergent validity test were calculated as suggested by Fornell and Larcker (1981).

\subsubsection{Measurement model for exogenous variables- Model fit indices}

The final model fit indices for measurement model for exogenous variable were within accepted levels.

Table 3 Model fit indices for measurement model of exogenous variables

\begin{tabular}{|l|l|l|l|}
\hline $\begin{array}{c}\text { Relative chi- } \\
\text { square }\end{array}$ & \multicolumn{1}{|c|}{ CFI } & TLI & RMSEA \\
\hline 1.607 & 0.928 & 0.917 & 0.069 \\
\hline
\end{tabular}


Pattnaik \& Pattnaik: Relationships between Green Supply Chain Drivers, Triple Bottom Line Sustainability and Operational Performance 204

Operations and Supply Chain Management 12(4) pp. 198 - 211 (C) 2019

4.1.3.2 Reliability, convergent and discriminant validity test for exogenous variables

In this measurement model, all the items had a standardized regression weight of more than 0.58 on their respective constructs. The Cronbach's $\alpha$ value for all constructs were above 0.8 . The composite Reliability (CR) and Average Variance Extracted (AVE) were more than 0.7 and 0.5 respectively for all the constructs satisfying the convergent validity conditions given by Fornell and Larcker (1981) and proving the internal consistency of the items with their constructs. AVE values of the constructs were found to be more than squared correlation between the constructs satisfying the discriminant validity conditions (Fornell and Larcker, 1981). Reliability test and convergent validity test results are shown in Table 4. Discriminant validity test results are shown in Table $\mathbf{5}$.

Table 4 Reliability and convergent validity test results of exogenous variables

\begin{tabular}{|c|c|c|c|c|}
\hline $\begin{array}{c}\text { Exogenous } \\
\text { variables }\end{array}$ & $\begin{array}{c}\text { No of } \\
\text { items }\end{array}$ & $\begin{array}{c}\text { Cronbach's } \\
\boldsymbol{\alpha}\end{array}$ & $\begin{array}{c}\text { Composite } \\
\text { Reliability } \\
\text { (CR) }\end{array}$ & AVE \\
\hline SCP & 5 & 0.884 & 0.876 & 0.590 \\
EP & 6 & 0.860 & 0.860 & 0.511 \\
EDP & 5 & 0.829 & 0.828 & 0.508 \\
SCC & 5 & 0.898 & 0.892 & 0.626 \\
\hline
\end{tabular}

4.1.3.3 Measurement model for endogenous variables Model fit indices

The final model fit indices for the measurement model of endogenous variables were as given below and within accepted levels.

Table 6 Model fit indices for measurement model of endogenous variables

\begin{tabular}{|l|c|c|c|}
\hline $\begin{array}{c}\text { Relative Chi- } \\
\text { Square }\end{array}$ & CFI & TLI & RMSEA \\
\hline 1.712 & 0.940 & 0.927 & 0.074 \\
\hline
\end{tabular}

\subsubsection{Reliability, convergent and discriminant validity test} for endogenous variables

In this measurement model, all the items had a standardized regression weight of more than 0.64 on their respective constructs. The Cronbach's $\alpha$ value for all constructs were above 0.8 . CR and AVE were more than 0.7 and 0.5 respectively for all the constructs satisfying the convergent validity conditions. AVE values of the constructs were found to be more than squared correlation between the constructs satisfying the discriminant validity condition. Reliability test and convergent validity test results for this measurement model are shown in Table 7. Discriminant validity test results are shown in Table 8.

Table 5 Discriminant validity test results of exogenous variables

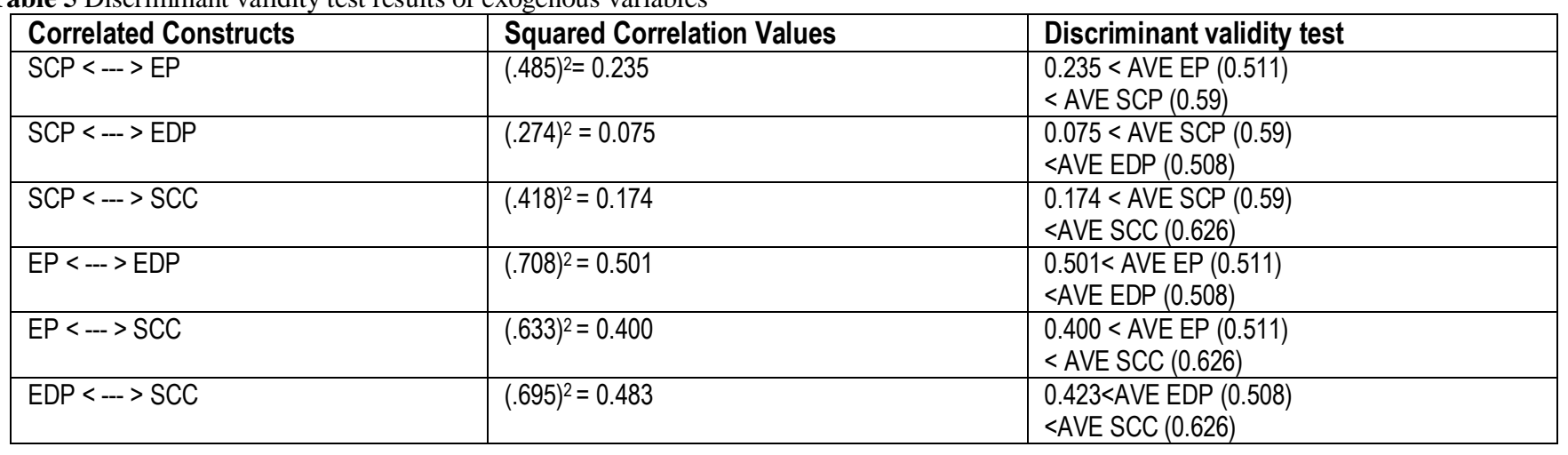

Table 7 Reliability and convergent validity test results of endogenous variables

\begin{tabular}{|l|l|l|l|l|}
\hline \multicolumn{1}{|c|}{ Endogenous variables } & No of items & Cronbach's $\boldsymbol{\alpha}$ & $\begin{array}{c}\text { Composite } \\
\text { Reliability (CR) }\end{array}$ & AVE \\
\hline EnvPerf & 4 & 0.835 & 0.841 & .572 \\
SocPerf & 5 & 0.866 & 0.866 & .567 \\
EcoPerf & 4 & 0.886 & 0.888 & .666 \\
OperPerf & 3 & 0.845 & 0.853 & .661 \\
\hline
\end{tabular}

Table 8 Discriminant validity test result of endogenous variables

\begin{tabular}{|l|l|l|}
\hline Correlated constructs & Squared correlation values & Discriminant validity test \\
\hline EnvPerf< --- >SocPerf & $(.605)^{2}=0.366$ & $\begin{array}{l}0.366<\text { AVE EnvPerf }(0.572) \\
<\text { AVE SocPerf }(0.567)\end{array}$ \\
\hline EnvPerf< --- >EcoPerf & $(.494)^{2}=0.244$ & $\begin{array}{l}0.244<\text { AVE EnvPerf }(0.572) \\
<\text { AVE EcoPerf }(0.666)\end{array}$ \\
\hline EnvPerf< --- >OperPerf & $(.367)^{2}=0.134$ & $\begin{array}{l}0.134<\text { AVE EnvPerf }(0.572) \\
<\text { AVE OperPerf }(0.661)\end{array}$ \\
\hline SocPerf< --- >EcoPerf & $(.606)^{2}=0.367$ & $\begin{array}{l}0.367<\text { AVE SocPerf }(0.567) \\
<\text { AVE EcoPerf }(0.666)\end{array}$ \\
\hline SocPerf< --- >OperPerf & $(.391)^{2}=0.152$ & $\begin{array}{l}0.152<\text { AVE SocPerf }(0.567) \\
<\text { AVE OperPerf }(0.661)\end{array}$ \\
\hline EcoPerf< --- >OperPerf & $(.692)^{2}=0.478$ & $\begin{array}{l}0.478<\text { AVE EcoPerf }(0.666) \\
<\text { AVE OperPerf }(0.661)\end{array}$ \\
\hline
\end{tabular}




\subsection{Structural Model}

In the second stage of the analysis, the structural equation model was developed to test the casual relationships between the constructs in order to establish the hypotheses. This structural model represented the conceptual model of this research. The value of CFI was found to be 0.79 , RMSEA was 0.087, relative chi-square was 1.979 and TLI was 0.77 . These values suggested re-specification of the model by observing the Modification indices (MI) values. Since, the MI for the regression weight between Eco-design and Production and Social Performance was very high (32). Eco-design and Production includes production of nonhazardous substances which influence the health and safety of the employees and people around the manufacturing unit which is the social responsibility of the company. Cruz (2008) has also pointed out that eco-design has now become the social responsibility of the companies. With this theoretical link thought by the authors, a path was added between these constructs. The model fit values have been presented in Table 9.
Table 9 Model fit indices of structural model

\begin{tabular}{|c|c|c|c|}
\hline $\begin{array}{c}\text { Relative Chi- } \\
\text { Square }\end{array}$ & CFI & TLI & RMSEA \\
\hline 1.440 & 0.935 & 0.923 & 0.058 \\
\hline
\end{tabular}

Minimum value of CFI recommended now-a-days is 0.95 . However, $\mathrm{CFI} \geq 0.9$ was traditionally suggested and it was found that Carter and Jennings (2004) have also considered $\mathrm{CFI}=0.931$ as appropriate. Thus $\mathrm{CFI}=0.935$ was accepted to be appropriate in this study.

Thus, from model fit indices values it was found that the model had an acceptable fit.

\subsection{Hypotheses testing and results}

The paths between the constructs in the structural equation model were analyzed to test the hypotheses posed in this study. The standardized regression weights and the significance level of each path have been presented in the Table 10.

Table 10 Structural path analysis results

\begin{tabular}{|c|c|c|}
\hline Structural Paths & $\begin{array}{l}\text { Standardized } \\
\text { regression } \\
\text { weight }(\beta)\end{array}$ & $\begin{array}{l}\text { Significance } \\
\text { level(p value) }\end{array}$ \\
\hline Supplier\& Customer Pressure $\longrightarrow$ Social Performance & $.275^{*}$ & .035 \\
\hline Supplier\& Customer Pressure $\longrightarrow$ Environmental Performance & .020 & .853 \\
\hline Environmental Purchasing $\longrightarrow$ Environmental Performance & .025 & .791 \\
\hline Environmental Purchasing $\longrightarrow$ Economic Performance & $.218^{*}$ & .049 \\
\hline Eco-Design and Production $\longrightarrow$ Environmental Performance & $.443^{*}$ & .012 \\
\hline Eco-Design and Production $\longrightarrow$ Economic Performance & $.576^{\star * *}$ & *** \\
\hline Eco-Design and Production $\longrightarrow$ Social Performance & $.540^{* * *}$ & *** \\
\hline Supplier \& Customer Collaboration $\longrightarrow$ Environmental Performance & -0.018 & .903 \\
\hline Environmental Performance $\longrightarrow$ Operational Performance & .019 & .853 \\
\hline Social Performance $\longrightarrow$ Operational Performance & $.204^{*}$ & .031 \\
\hline Economic Performance $\longrightarrow$ Operational Performance & $.615^{* * \star}$ & *** \\
\hline
\end{tabular}

Note: $* \mathrm{p}<0.05, * * * \mathrm{p}<0.001$

From the structural path analysis, it was found that out of 10 hypotheses proposed, 6 were supported. The study supported hypothesis $\mathrm{H} 2(\beta=.275, \mathrm{p}<0.05)$ indicating a direct relationship between supplier customer pressure and social performance. Support of $\mathrm{H} 4(\beta=.218$, $\mathrm{p}<0.05)$ suggested that environmental purchasing has a positive effect on economic performance. Both H5 $(\beta=.443, \mathrm{p}<0.05)$ and H6 $(\beta=.576, \mathrm{p}<0.001)$ were supported signifying that eco-design and production is positively related to environmental performance and economic performance. In addition to those, the path added from eco-design and production to social performance was also supported $(\beta=$ $.615, \mathrm{p}<0.001)$. Hypotheses H9 $(\beta=.204, \mathrm{p}<0.05)$ and H10 $(\beta=.615, \mathrm{p}<0.001)$ were supported which signified that social and economic performance are positively related to operational performance. The relationship of supplier and customer environmental pressure, environmental purchasing and supplier and customer environmental collaboration with environmental performance was insignificant leading to rejection of hypothesis $\mathrm{H} 1, \mathrm{H} 3$ and $\mathrm{H} 7$ respectively. Hypothesis $\mathrm{H} 8$ proposing the positive relationship between environmental performance and operational performance was rejected too.

\subsection{Graphical representation of the model and structural path estimates}

The graphical representation of the model has been presented in Figure 1. The solid line between the constructs denotes a significant relationship between them and dotted line indicates an insignificant relationship between the constructs. The blue line indicates the path added during the modeling which was found to be significant. 


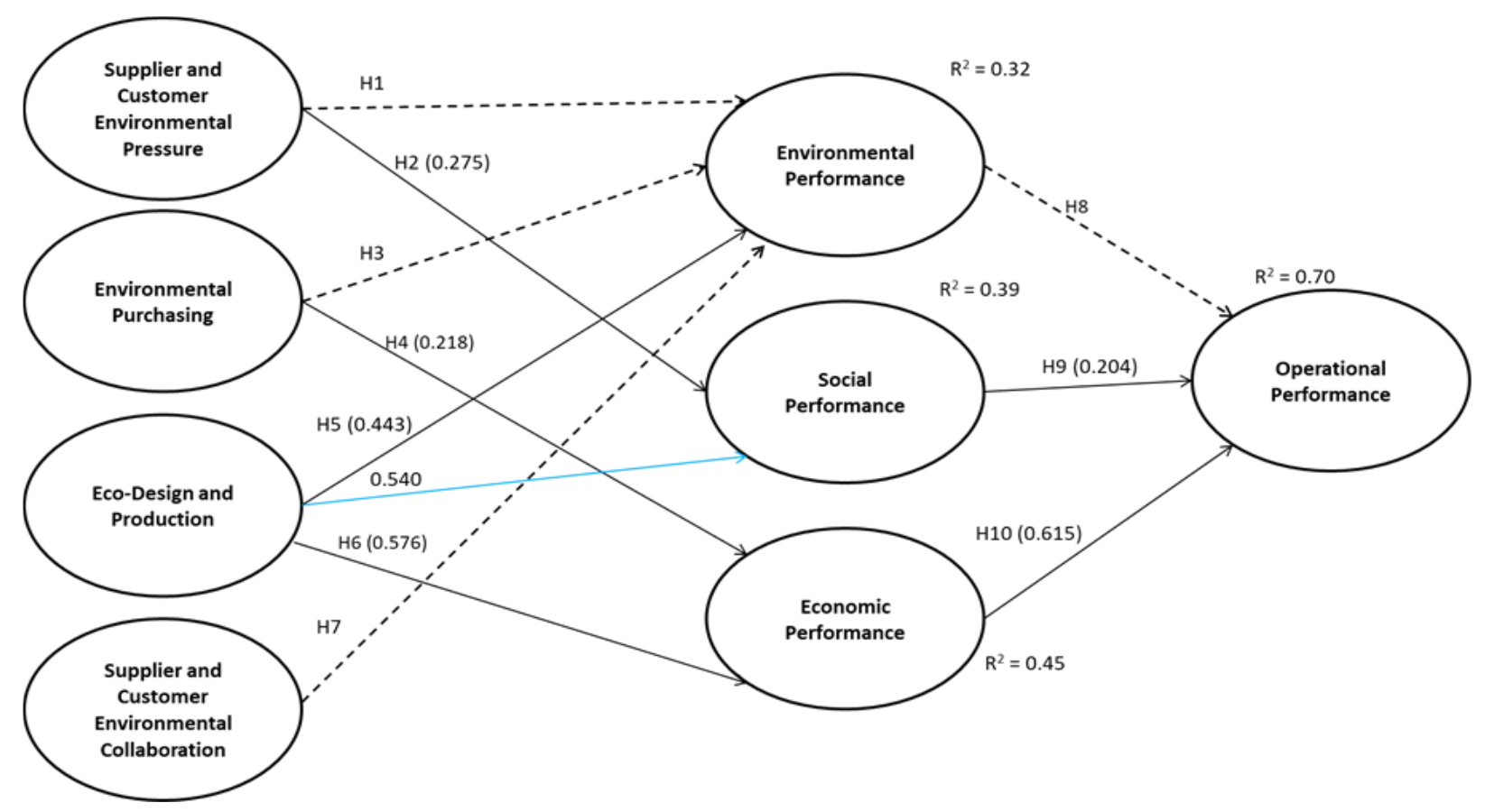

Figure 1. Graphical representation of the structural model and the structural path estimates

The $\mathrm{R}^{2}$ for Operational Performance was 0.70 implying that environmental performance, social performance and economic performance together account for $70 \%$ of variance in operational performance. However, standardized regression of economic performance on operational performance was 0.615 which was much higher than those of environmental performance and social performance on operational performance. This means that maximum variance in operational performance is explained by economic performance. Similarly, $\mathrm{R}^{2}$ for environmental performance was 0.32 , for social performance was 0.39 and for economic performance was 0.45 . From the regression weight of the paths between the environmental drivers and the sustainability performances in the structural equation model, it was found that eco-design and production explained maximum of the variance in the sustainable performances.

\section{DISCUSSION \& FINDINGS}

Hypothesis H5 suggested that eco-design and production influenced the environmental performance positively. The support of this hypothesis in this study provides an insight that UK manufacturing companies are engaged in designing products that consume less energy and in producing recyclable, reusable and non-hazardous materials (Famiyeh et al., 2018; Zhu et al., 2007; Zhu et al., 2005), thereby proving that the companies are becoming responsible towards saving the environment. Companies' involvement in eco-design and production has significantly increased their environmental performance by decreasing use of harmful materials, reducing wastes and saving energy by conservation and efficiency improvements (Hong et al., 2018; Paulraj, 2011). It was also found that eco-design and production significantly improved the economic performance of the company as the hypothesis H6 was supported. Carter and Rogers (2008) mentioned that too many environmental initiatives can either improve or harm the economic performance of the company. Ciccullo et al. (2018) debated on how firms could be environmentally and socially sustainable while remaining lean and agile. The findings in this study emphasized that in UK manufacturing sector, eco-design and production which is an environmental performance initiative can also improve the economic performance of the company. This finding is helpful for the manufacturing companies in UK who fear that environmental initiatives might negatively affect the bottom line and resist re-strategizing their production systems to achieve environmental sustainability. This result suggested that environmental initiative can also influence the economic performance of the company positively. The additional path added from eco-design and production to social performance was significant and positive. This could be because production of non-hazardous substances improves the health and safety conditions for the employees which are the social responsibility of the company. Further, if the company is engaged in eco-friendly production, the disposal of the waste that is generated during the production process won't pose serious threat to the health and safety of the community nearby the manufacturing industry. This also supports Cruz (2008) ideology that environmental design is a part of social responsibility now. Support of H4which proposed that environmental purchasing positively influences the economic performance of the company indicates that if company purchases materials those are recyclable and reusable can improve the economic performance. This is an indication to the purchasing managers who should re-define their strategies of purchasing and should stress upon purchasing materials those are reusable and recyclable to provide financial benefits to the company. This result is also consistent with the observations of Darnall et al. (2018) or Zsidisin and Siferd (2001) that environmental purchasing 
can provide benefits to the company by reducing disposal and liability costs, conserving resources, and improving an organization's public image. The companies using recyclable and reusable products do not have to make further investments in disposing these materials, thus adding to its financial benefits. Therefore, purchasing managers are increasingly getting interested in recyclable and reusable materials (Darnall et al., 2018; Warner and Ryall, 2001).

Surprisingly, the hypothesis $\mathrm{H} 3$ proposing the positive relationship between environmental purchasing and environmental performance was not supported in the context of this study. This initiates a thought that environmental purchasing might not be a direct driver for environmental performance of the companies involved this study. However, environmental purchasing indirectly improves the environmental performance of the company by supporting the eco-production which requires purchasing of environment friendly goods. However, further research has to be done to analyze this relationship.

The significance of hypothesis $\mathrm{H} 2$ that states supplier and customer pressure positively affect the social performance suggests that UK manufacturing companies prefer their suppliers and customers to be socially responsible. This is a clear indication that the UK manufacturing companies understand their role in improving quality of life and well-being of the society (Lindgreen et al., 2008). They prefer purchasing from the suppliers who take measures to improve health and safety conditions of the employees and that of community at large and reduce the negative environmental impact. Hypothesis, H1states that the supplier and customer pressure have a positive impact on the environmental performance, but it was not supported in the analysis. This might be because the items used to measure supplier and customer pressure were more inclined towards the social issues which is a methodological limitation of the study.

Hypothesis $\mathrm{H} 7$ which states that supplier and customer collaboration has positive effect on the environmental performance was also not supported. The result suggested that supplier and customer collaboration is not an important driver for the environmental performance. However, existing literature provides a strong support for supplier collaboration in improving environmental performance. The items of supplier collaboration were adapted from Paulraj (2011). He has used supplier collaboration as a factor of sustainable supply chain and has found that sustainable supply chain has a significant positive impact on sustainable performances in the US firms. In this study supplier and customer collaboration have been used as a single construct. Historically, relatively less attention has been paid to the downstream customer side on environmental issues (Vachon and Klassen, 2006). So, it could be possible that environmental customer collaboration was not considered important for improving environmental performance by the respondents. Use of supplier collaboration and customer collaboration as two different constructs may give more interesting results to understand the relationship separately between the supplier and customer collaboration with environmental performance.

Thus, from this empirical investigation it was found that drivers of GSC do have a positive effect on the social and economic performance. The significant and positive relationship of eco-design and production with all the three sustainable performances is a strong evident that the three dimensions of sustainability are not stand-alone concept. It also demonstrates that wise selection of the environmentally sustainable initiative can make an organization truly sustainable by improving its environmental, social and economic performance. By analyzing the $\mathrm{R}^{2}$ value, it was observed that the environmental drivers explain $45 \%$ of variance in the economic performance, $39 \%$ of variance of social performance and $32 \%$ of variance in environmental performance. Further, all the path estimates were positive except for the path between supplier and customer environmental collaboration and environmental performance. This clearly indicates that environmental drivers have significantly higher positive influence on the economic and social performance than environmental performance. The results from this study strongly convey that these environmental drivers are also strong drivers of social and economic performance.

The hypothesis H10 that stated the relationship between economic performance and operational performance was on the basis of an assumption that if operational effectiveness(reduction in lead time, better product design etc.) can improve economic performance, then economic performance can also have a positive impact on operational performance. There was a strong significant support for this hypothesis, justifying the assumption that companies which are economically strong can invest more on developing their innovation and technology to increase their operational efficiencies and effectiveness by decreasing the operational cost, lead time, improving quality and design of the products etc.

Gimenez et al. (2018) or Pullman et al. (2009) indicated that socially responsible practices improve product quality and reduce cost and this research results supports this observation. The support of hypothesis H9 suggested that social performances (improving community health and safety of the public as well as that of employees, increasing the awareness, and protection of claims and rights of people in the community) tend to affect the operational performance (operational costs, lead times, product quality, product design and reduction of waste) positively. Providing a healthy and risk-free workplace for the employees and taking initiatives to improve community health and welfare is the social responsibility of the company. In order to fulfill the social responsibility, the company improves its operational systems which enhance the efficiency and the effectiveness of its operations. For Example, design of production system that considers the health and safety factors of the employees have a positive effect on the quality of products by limiting the use of hazardous substances in the process. Furthermore, healthy and safe working condition also increases the soft aspects (like moral) of people which have an effect on the operational effectiveness of the company. Result of hypothesis H8 was not consistent with the statement of Melnyk et al. (2003) or Wilson (2015) that environmental management system can improve the operational performance. A possible explanation for this could be that out of the organizations that responded to the survey, 75 were considered older (age above 20 years) and 55 were considered younger (age between 1-20 years) and as stated by Zsidisin and Hendrick (1998), older companies are 
slightly reluctant in taking environmental initiatives that would require huge investments to change existing systems. Hence, managers from older companies might not perceive any direct relationship between environmental performance and operational performance of the firm. Further, $\mathrm{Wu}$ and Pagell (2011) also stated that environmental initiatives are a trade off with economic profits and do not yield short-term operational gains. This notion could also have played on minds of managers while responding, leading to the rejection of the proposed hypothesis, H8. This provokes us to explore an indirect relationship of environmental performance to operational performance through economic or social performance.

The $\mathrm{R}^{2}$ analysis suggested that $70 \%$ of the variance in operational performance is explained by the sustainable performances and economic performance explains maximum of the variance. This indicates that companies having a strong economy will certainly have better operational performance than others and in turn, better operational performance would again lead to better economic performance.

Thus, in this study it was found that economic dimension of the sustainability had a strong positive impact on the operational performance of the UK manufacturing companies. The social performance also had a positive influence on the operational performance. The environmental performance did not have a direct relationship with the operational performance, within the context of the study.

\section{CONCLUSION AND DIRECTIONS FOR FUTURE RESEARCH}

This research makes a significant contribution to the sustainability literature by empirically investigating the effect of GSC drivers on all the three TBL dimensions environmental, social and economic and then testing the influence of TBL performances on the operational performance of UK manufacturing firms. While most sustainability studies tend to focus on environmental parameters, this study contributes uniquely to the gap area of TBL literature within sustainability research. Further, it provides interesting insights into TBL literature in the context of UK manufacturing firms that had not been done before. The study revealed that Eco-Design and Production, primarily considered to be an environmental driver, is actually a TBL driver as it influenced all the three dimensions of TBL sustainability. Environmental purchasing emerged as a significant driver of economic performance but unexpectedly, had no significant influence on environmental performance. Supplier and Customer Pressure did influence social performance of firms. However, Supplier and Customer Collaboration failed to have any significant influence on environmental performance. Against common perception, social and economic performance proved to be stronger influencer of operational performance as compared to environmental performance. This reinforces the importance of implementing TBL sustainability model in firms instead of just focusing on environmental strategies.
To take this research forward, the TBL model developed in the study could be replicated across different samples (sectors as well as countries) to compare findings and draw richer insights. The sample of this study included a wide range of companies belonging to different manufacturing industries. For example, there were respondents from bed and mattresses industries to respondents from electronic equipment and chemical manufacturing companies. The environmental concerns for the companies will differ depending on the products they manufacture. Therefore, the model of this study can be qualitatively analyzed through interviews and case studies in companies belonging to specific manufacturing industry (e.g. Electronics equipment manufacturing companies in UK) in further research. This will provide a pragmatic view of application of the findings in the industry. Future research could also be done on unsupported hypotheses by introducing possible mediators, thereby, exploring the possibility of indirect relationship between those variables. Also, this study used only four environmental drivers. Future studies could introduce other drivers into the model to test their influence on TBL sustainability.

\section{REFERENCES}

Ahi, P., and Searcy, C. (2015), Assessing sustainability in the supply chain: A triple bottom line approach. Applied Mathematical Modelling 39(10-11), pp. 2882-2896.

Ahmad, S., Wong, K. Y., and Rajoo, S. (2019), Sustainability indicators for manufacturing sectors: A literature survey and maturity analysis from the triple-bottom line perspective, Journal of Manufacturing Technology Management 30(2), pp. 312-334.

Alhaddi, H. (2015), Triple bottom line and sustainability: A literature review, Business and Management Studies 1(2), pp. 6-10.

Bals, L., and Tate, W. (2017), Implementing Triple Bottom Line Sustainability into Global Supply Chains, Routledge, New York, NY.

Bastas, A., and Liyanage, K. (2018). Sustainable supply chain quality management: A systematic review, Journal of Cleaner Production 181, pp. 726-744.

Bayraktar, E., Tatoglu, E., and Zaim, S. (2007), The impact of supply chain management practices on performance of SMEs, Industrial Management and Data Systems 107(1), pp. 103124.

Bowen, F. E., Cousins, P. D., Lamming, R. C., and Faruk, A. C. (2002), Horses for courses: explaining the gap between the theory and practice of green supply, Greener Management International Autumn 35, pp. 41-60.

Carter, C. R. (2005), Purchasing social responsibility and firm performance: the key mediating roles of organizational learning and supplier performance, International Journal of Physical Distribution \& Logistics Management 35(3), pp. 177-194.

Carter, C. R., and Jennings, M. M. (2002), Logistics social responsibility: an integrative Framework, Journal of Business Logistics 23(1), pp. 145-180.

Carter, C. R., and Jennings, M. M. (2004), The role of purchasing in corporate social responsibility: a structural equation analysis, Journal of Business Logistics 25(1), pp. 145-186.

Carter, C. R., Kale, R., and Grimm, C. M., (2000), Environmental purchasing and firm performance: an empirical investigation, Transportation Research Part E: Logistics and Transportation Review 36(3), pp. 219-228. 
Carter, C. R., and Rogers, D. S. (2008), A framework of sustainable supply chain management: moving toward new theory, International Journal of Physical Distribution \& Logistics Management 38(5), pp. 360-387.

Ciccullo, F., Pero, M., Caridi, M., Gosling, J., and Purvis, L. (2018), Integrating the environmental and social sustainability pillars into the lean and agile supply chain management paradigms: A literature review and future research directions, Journal of Cleaner Production172, pp. 2336-2350.

Corsten, D., and Felde, J., (2005), Exploring the performance effects of key-supplier collaboration - an empirical investigation into Swiss buyer-supplier relationships, International Journal of Physical Distribution \& Logistics Management 35(6), pp. 445-461.

Cruz, J. M. (2008), Dynamics of supply chain networks with corporate social responsibility through integrated environmental decision-making, European Journal of Operational Research 184(3), pp. 1005-1031.

Darnall, N., Hsueh, L., Stritch, J. M., and Bretchneider, S. (2018), Environmental purchasing in the City of Phoenix. In S. Garren, and S. Brinkman (Eds.), Handbook of Sustainability: Case Studies and Practical Solutions (pp. 485-502), Palgrave Macmillan, London, UK.

Delmas, M., and Montiel, I. (2009), Greening the supply chain: when is customer pressure effective? Journal of Economics \& Management Strategy 18(1), pp. 171-201.

Eltayeb, T. K., Zailani S., and Ramayah, T. (2011), Green supply chain initiatives among certified companies in Malaysia and environmental sustainability: investigating the outcomes, Resources, Conservation and Recycling 55(5), pp. 495-506.

Faisal, M.N, (2010), Sustainable supply chains: a study of interaction among the enablers, Business Process Management Journal 16(3), pp. 508-529.

Famiyeh, S., Adaku, E., Amoako-Gyampah, K., Asante-Darko, D., and Amoatey, C. T. (2018), Environmental management practices, operational competitiveness and environmental performance: Empirical evidence from a developing country, Journal of Manufacturing Technology Management 29(3), pp. 588-607.

Feng, M., Yu, W., Wang, X., Wong, C. Y., Xu, M., and Xiao, Z. (2018), Green supply chain management and financial performance: The mediating roles of operational and environmental performance, Business Strategy and the Environment 27(7), pp. 811-824.

Field, A.P. (2005), Discovering statistics using SPSS (2 ${ }^{\text {nd }} E d$.), SAGE Publication Ltd., London, UK.

Fornell, C., and Larcker, D. F. (1981), Evaluating Structural Equation Models with Unobservable Variables and Measurement Error, Journal of Marketing Research 18(1), pp. 39-50.

Gimenez, C., Sierra, V., Sancha, C., Rodón, J., and Markovic, S. (2018), The impact of environmental and social practices on the triple bottom line: A mediated model, In A. Lindgreen, C. Vallaster, S. Yousofzai, and B. Hirsch (Eds.), Measuring and Controlling Sustainability (pp. 141-165), Routledge, London, UK.

Gao, J., and Bansal, P. (2013), Instrumental and integrative logics in business sustainability, Journal of Business Ethics 112(2), pp. 241-255.

Gunasekaran, A., and Spalanzani, A. (2012), Sustainability of manufacturing and services: Investigations for research and applications, International Journal of Production Economics 140(1), pp. 35-47.

Hair, J. F. Jr., Anderson, R. E., Tatham, R. L. and Black, W. C. (2008), Multivariate data analysis, Prentice Hall, New Jersey, NJ.

Hemel, C. G. V., Hartman, R., and Bottcher, H. (1997), The IC EcoDesign project: results and lessons from a Dutch initiative to implement eco-design in small and medium-sized
Companies, The Journal of Sustainable Product Design 2(2), pp. 7-18.

Hick, S. (2000), Morals make the money, Austrian CPA70, pp. $72-$ 3.

Hong, J., Zhang, Y., and Ding, M. (2018). Sustainable supply chain management practices, supply chain dynamic capabilities, and enterprise performance, Journal of Cleaner Production 172 , pp. 3508-3519.

$\mathrm{Hu}$, A. H., and Hsu, C. W. (2010), Critical factors for implementing green supply chain management practice: An empirical study of electrical and electronics industries in Taiwan, Management Research Review 33(6), pp. 586-608.

Hussain, N., Rigoni, U., and Orij, R. P. (2018), Corporate governance and sustainability performance: Analysis of triple bottom line performance, Journal of Business Ethics 149(2), pp. 411-432.

Judge, W. Q., and Douglas, T. J. (1998), Performance implications of incorporating natural environmental issues into the Strategic Planning Process: An Empirical Assessment, Journal of Management Studies 35(2), pp. 241-262.

Junior, A. N., de Oliveira, M. C., and Helleno, A. L. (2018), Sustainability evaluation model for manufacturing systems based on the correlation between triple bottom line dimensions and balanced scorecard perspectives, Journal of Cleaner Production 190, pp. 84-93.

Kiron, D., Kruschwitz, N., Haanaes, K., Reeves, M., FuiszKehrbach, S. K., and Kell, G. (2015), Joining forces: Collaboration and leadership for sustainability, MIT Sloan Management Review 56(3), pp. 1-31.

Klumpp, M. (2018), How to Achieve Supply Chain Sustainability Efficiently? Taming the Triple Bottom Line Split Business Cycle. Sustainability 10(2), pp. 397-419.

Lindgreen, A., Antioco, M., Harness, D., and Van der Sloot, R. (2008), Purchasing and Marketing of Social and Environmental Sustainability for High-Tech Medical Equipment, Journal of Business Ethics 85(2), pp. 445-462.

Linton, J. D., Klassen, R., and Jayaraman, V. (2007), Sustainable supply chains: An introduction, Journal of Operations Management 25(6), pp. 1075-1082.

Liu, Y., Blome, C., Sanderson, J., and Paulraj, A. (2018). Supply chain integration capabilities, green design strategy and performance: a comparative study in the auto industry, Supply Chain Management: An International Journal 23(5), pp. 431443.

McLean, S. R. (2019), Hey Google: The Business Case of Environmental Sustainability in Developing Corporate Social Responsibility, Dialogues: Undergraduate Research in Philosophy, History, and Politics 1(1), p. 6.

Melnyk, S. A., Sroufe, R. P., and Calantone, R. (2003), Assessing the impact of environmental management systems on corporate and environmental performance, Journal of Operations Management 21(3), pp. 329-351.

Ozanne, L. K., Phipps, M., Weaver, T., Carrington, M., Luchs, M., Catlin, J., ... and Williams, J. (2016), Managing the tensions at the intersection of the triple bottom line: A paradox theory approach to sustainability management, Journal of Public Policy \& Marketing 35(2), pp. 249-261.

Paulraj, A. (2011), Understanding the relationships between internal resources and capabilities, sustainable supply management and organizational sustainability, Journal of Supply Chain Management 47(1), pp. 19-37.

Pullman, M. E., Maloni, M. J., and Carter, C. R. (2009), Food for thought: social versus environmental sustainability practices and performance outcomes, Journal of Supply Chain Management 45(4), pp. 38-54.

Quarshie, A. M., Salmi, A., and Leuschner, R. (2016), Sustainability and corporate social responsibility in supply chains: The state of research in supply chain management and 
business ethics journals, Journal of Purchasing and Supply Management 22(2), pp. 82-97.

Rajeev, A., Pati, R. K., Padhi, S. S., and Govindan, K. (2017), Evolution of sustainability in supply chain management: A literature review, Journal of Cleaner Production 162, pp. 299-314.

Rao, P. (2002), Greening the supply chain: a new initiative in South East Asia, International Journal of Operations and Production Management 22(6), pp. 632-655.

Rao, P., and Holt, D. (2005), Do green supply chains lead to competitiveness and economic performance? International Journal of Operations \& Production Management 25(9), pp. 898-916.

Salam, M. A. (2008), Corporate Social Responsibility in Purchasing and Supply Chain, Journal of Business Ethics 85, pp. 355370.

Sarkis, J. (2001), Manufacturing's role in corporate environmental sustainability: concerns for the new millennium, International Journal of Operations \&Production Management 21(5-6), pp. 666-686.

Sarkis, J., (2003), A strategic decision framework for green supply chain management, Journal of Cleaner Production 11(4), pp.397-409.

Shankar, K. M., Kannan, D., and Kumar, P. U. (2017), Analyzing sustainable manufacturing practices-A case study in Indian context, Journal of Cleaner Production 164, pp. 1332-1343.

Shrivastava (1995), The role of corporations in achieving ecological sustainability, Academy of Management Review 20(4), pp. 936-960.

Svensson, G., Høgevold, N., Ferro, C., Varela, J. C. S., Padin, C., and Wagner, B. (2016), A triple bottom line dominant logic for business sustainability: framework and empirical findings, Journal of Business-to-Business Marketing 23(2), pp. 153-188.

Vachon, S. (2007), Green supply chain practices and the selection of environmental technologies, International Journal of Production Research 45(18/19), pp. 4357-4379.

Vachon, S., and Klassen, R.D. (2006), Extending green practices across the supply chain:the impact of upstream and downstream integration, International Journal of Operations \& Production Management 26(7), pp. 795-821.

Van der Byl, C. A., and Slawinski, N. (2015), Embracing tensions in corporate sustainability: A review of research from winwins and trade-offs to paradoxes and beyond. Organization \& Environment 28(1), pp. 54-79.

Walker, H., Sisto, L. D., and McBain, D. (2008), Drivers and barriers to environmental supply chain management practices: Lessons from the public and private sectors, Journal of Purchasing \& Supply Management 14(1), pp. 6985.
Warner, K. E. and Ryall, C. (2001), Greener purchasing activities within UK local authorities, Eco Management and Auditing 8 (1), pp. 36-45.

Wilson, J. P. (2015), The triple bottom line: Undertaking an economic, social, and environmental retail sustainability strategy, International Journal of Retail \& Distribution Management 43(4-5), pp. 432-447.

Wu, Z., and Pagell, M. (2011), Balancing priorities: Decisionmaking in sustainable supply chain management, Journal of Operations Management 29(6), pp. 577-590.

Yan, M. R., Chien, K. M., and Yang, T. N. (2016), Green Component Procurement Collaboration for Improving Supply Chain Management in the High Technology Industries: A Case Study from the Systems Perspective, Sustainability 2016(8), p. 105.

Yook, K. H., Choi, J. H., and Suresh, N. C. (2018), Linking green purchasing capabilities to environmental and economic performance: The moderating role of firm size, Journal of Purchasing and Supply Management 24(4), pp. 326-337.

Zhu, Q., Geng, Y., Fujita, T., and Hashimoto, S. (2010), Green supply chain management in leading manufacturers: Case studies in Japanese large companies, Management Research Review 33 (4), pp. 380-392.

Zhu, Q., and Liu, Q. (2010), Eco-design planning in a Chinese telecommunication network Company: Benchmarking its parent company, Benchmarking: An International Journal 17 (3), pp. 363-37.

Zhu, Q., Qu, Y., Geng, Y., and Fujita, T. (2017), A comparison of regulatory awareness and green supply chain management practices among Chinese and Japanese manufacturers, Business Strategy and the Environment 26(1), pp. 18-30.

Zhu, Q., and Sarkis, J. (2006), Aninter-sectoral comparison of green supply chain management in China: drivers and practices, Journal of Cleaner Production 14, pp. 472- 486.

Zhu, Q., Sarkis, J., and Geng, Y. (2005), Green supply chain management in China: pressures, practices and performance, International Journal of Operations \& Production Management 25 (5), pp. 449-468.

Zhu, Q., Sarkis, J., and Lai, K.H. (2007), Green supply chain management in China: pressures, practices and performance within the Chinese automobile industry, Journal of Cleaner Production 15 (1), pp. 1041-1052.

Zsidisin, G.A., and Hendrick, T.E. (1998), Purchasing involvement in environmental issues: a multi country perspective, Industrial Management and Data Systems 98(7), pp. 313-320.

Zsidisin, G.A., and Siferd, S.P. (2001), Environmental purchasing: a framework for theory development, European Journal of Purchasing \& Supply Management 7 (1), pp. 61-73.

Susmita Pattnaik is currently serving as the Manager - HR and operations in an Indian IT startup and has around 9 years of work experience. As a dynamic HR \& Operations manager, she has led several initiatives in her organization to improve business profitability as well as employee productivity. She is a post-graduate in Operations Management from Manchester Business School and has also obtained a post-graduate HR degree from Pune University, India. She specializes in the areas of talent acquisition, talent development and engagement, and business process re-engineering. Her research interests include sustainability and employee performance.

Subhra Pattnaik is a professor in Xavier School of Human Resource Management, Xavier University Bhubaneswar. She has around 11 years of work experience, spanning across consulting and academia. She specializes in the areas of performance management, compensation management, and talent assessment. Her research interests lies in areas such as sustainability, diversity and inclusion, organization justice, and employee performance and she has published papers on them in tiered journals. A passionate trainer, Subhra has conducted several corporate trainings and leadership workshops for several organizations across diverse industries. 